\title{
Health Risk Survey for Domestic Waste Management Agency Workers: Case Study on Kota Bharu Municipal Council (MPKB), Kelantan, Malaysia
}

\author{
Mohd Shah Hafizhin Aminuddin and Haliza Abdul Rahman
}

\begin{abstract}
Waste collector workers are potentially exposed to a variety of health risk and health symptoms factors. Collection of the domestic waste is also a job which requires repeated heavy physical activity such as lifting, carrying, pulling, and pushing. The objectives of this study were to conduct a survey to identify potential health risk and health symptom and also to identify the workers practice on personal protective equipment (PPE) during work. The subjects were all current employees of Kota Bharu Municipal Council in Kota Bharu, Kelantan. The survey questionnaire was completed by 103 waste collector workers $(n=103)$. The result of study indicates that waste collectors present a risk for the development of chronic respiratory symptoms (cough, phlegm, asphyxiate and wheezing) $(\mathbf{7 5 . 0 \%})$, common work related hazards (biological, physical, ergonomic, psychosocial, and chemical) $(62.3 \%)$, musculoskeletal symptoms (low back pain and elbow or wrist pain) $(90.8 \%$ ), dermatological symptoms (itchy and rashes) (70.3\%) and gastrointestinal symptoms (nausea and diarrhea) $(65.5 \%)$. Therefore, workers must alert and aware the potentials health risk and potentials health symptoms arising from their work.
\end{abstract}

Index Terms-Health risk assessment, Kota Bharu Municipal Council, solid waste, workers.

\section{INTRODUCTION}

Solid waste is one of the big issues in Malaysia and it increasing periodically of the increasing population and less participation or involvement of public in recycling activities. Currently, solid waste management has become common problem in urban area throughout the world, particularly in the fast-growing cities and towns of the developing countries such as Malaysia. Most of the wastes generated are from vast population increase, urbanization and industrialization, and also excessive consumption of modern daily life [1]. Increasingly of waste generated lead from the result of purchasing power enables the community to consume various types of products in their daily life. In case of waste production, about 30,000 tonnes of solid waste has sent directly into landfills daily [2]. From that, $41 \%$ are organic waste, $15 \%$ are plastic, $14 \%$ are paper, $8 \%$ are glass and $6 \%$

Manuscript received August 8, 2014; revised October 18, 2014.

Haliza Abdul Rahman is with the Department of Environmental and Occupational Health, Faculty of Medicine and Health Sciences, Universiti Putra Malaysia, 43400 UPM Serdang, Selangor, Malaysia (e-mail: dr.haliza@upm.edu.my). are tin [3]. In Malaysia, the trend of solid waste generated by Malaysian is increase annually by $3 \%$. The over generating of the waste nowadays have created the serious issues which is landfill. There are four major problems that relate to the landfill which are leachate generation and ground water contamination, methane production, incomplete decomposition, and settling [4].

Besides that, the solid waste management has a few related to the human health risk. There are many of the chemicals and biological agents used that contribute to the affecting the human health regarding on manage the solid waste which could give a direct or indirect health risk or impacts to human health [5]. The waste collector workers will face more amounts of exposure and risk during their work compare with other workers (Table I). The workers of waste itself may expose the same potential hazards as the general population, although the amount of exposure and their risk may differ [6]. Thus, in term number of the accident, the waste collection workers have been founded higher than the general workers [7].

TABLE I: REPORTED INJURIES TO EMPLOYEE IN THE WASTE MANAGEMENT AND RECYCLING INDUSTRY IN UK 2009-2011

\begin{tabular}{|l|c|c|c|c|}
\hline & $2009 / 2010$ & $2010 / 2011$ & & \\
\hline & $\begin{array}{c}\text { Rate } \\
\text { per } \\
100,000\end{array}$ & $\begin{array}{c}\text { Rate } \\
\text { per } \\
100,000\end{array}$ & $\begin{array}{c}\text { All } \\
\text { industry } \\
\text { rate per } \\
100,000\end{array}$ & $\begin{array}{c}\text { Comparison } \\
\text { between waste } \\
\text { \& recycle and all } \\
\text { industry rate }\end{array}$ \\
\hline $\begin{array}{l}\text { Fatal } \\
\text { Injuries }\end{array}$ & 2.3 & 8.4 & 0.5 & $\times 16.8$ \\
$\begin{array}{l}\text { Major } \\
\text { injuries }\end{array}$ & 390 & 405 & 99 & $\times 4.1$ \\
$\begin{array}{l}\text { Over 3 } \\
\text { days } \\
\text { injuries }\end{array}$ & 1596 & 1637 & 363 & $\times 4.5$ \\
$\begin{array}{l}\text { All } \\
\text { injuries }\end{array}$ & 1988 & 2050 & 462 & $\times 4.4$ \\
\hline
\end{tabular}

Source: [8]

Generally, the work process of the waste collector involved many considerable heavy lifting as well as other manual handling of containers, increasing the risk of musculoskeletal problems. In case of health risk the increasing of exposure to the bio-aerosols and volatile compounds may cause to elevated incidence sure to bio-related respiratory gastrointestinal and skin problems in waste collections compared to the general workers [6]. A comprehensive risk assessment of all activities related on the waste collection or waste management will allow the 
identification of necessary protection measures. Therefore, this study was done in order to conduct a HRA among waste collector workers in Kota Bharu Municipal Council. The main objective of the study was to access whether there is health risk affects outcomes among domestic waste collector due to the routine job as a waste collector worker.

\section{LITERATURE REVIEW}

\section{A. Seriousness of Health Risk and Their Effect to the Waste Collector Workers}

The collection of domestic waste is a hard work and can be dangerous to the workers. Waste collectors were more likely to cause gastrointestinal symptoms such as nausea and diarrhea [9]. The investigation suggested that certain dusts from domestic waste may cause airway inflammation [10]. The risk factors should be considered as an integrated entity such as technical factors (poor accessibility to the waste, design of equipment) may cause with high working rate, visual fatigue to the workers. Musculoskeletal problems are also a common health risk to waste collectors.

In addition, the workforce of workers on waste collection is larger than other types of work because there are come from waste collection activities, sorting of waste and disposal of waste into landfill. The workers of waste collector also may expose to the same potential hazards as the general population, although the amount of exposure and risk may differ. The incident of occupational accidents in waste collection workers has been found to be higher than the general workforce [6]. The main source of the workforces are come from considerable heavy lifting as well as other manual handling of containers, increasing the risk of musculoskeletal, exposure to bio-aerosols and volatile compounds that can lead to the work-related respiratory gastrointestinal and skin problems.

Furthermore, the waste collector workers has increases the risk of the development of chronic respiratory symptoms (cough, phlegm, wheezing, chronic bronchitis), musculoskeletal symptoms (low back pain and elbow/wrist pain) and tend to get injury caused by sharp objects [9]. On the other hand, the gastrointestinal symptoms such as diarrhea and nausea are well-known problems among occupational groups exposed to high concentrations of air-borne gram negative bacteria [9]. The results were showed a causal relation between gastrointestinal symptoms to the waste collector's activities. As handling and collection of waste may cause microorganisms and dust to become aerosolized, waste collectors are at risk of being exposed to bio-aerosols generated from the waste.

\section{B. Factors and Main Causes Influencing Injuries of Waste Collector Workers}

The waste collection activities account for the majority (75 to $80 \%$ ) of accidents within the industry. The particular safety and health areas that should be considered are musculoskeletal injuries, slips and trips, transport movement, PPE, personal hygiene and hoist or receptacle compatibility. In addition, the recent studies have indicated that the high rate of gastrointestinal problems, irritation of the eye and skin, and symptoms of organic dust toxic syndrome (influenza-like symptoms, cough, muscle pains, fever, fatigue and headache) have been reported among workers collecting the domestic waste [7]. Moreover, there are health risk or symptoms of the domestic waste collectors were affected to the upper airway inflammation and respiratory symptoms [11].

\section{Types of Major Occupational Health Problems for Waste Collector Workers}

Occupational accidents can be defined as a discrete occurrence in the course of work, which leads to physical or mental harm. The most commonly reported accidents in the waste collectors were accident (in general), fractures, sprains, wounds, thermal accidents, soft tissue accidents, chemical burns and poisoning. On average, each waste collector lost 9.5 working days per year because of occupational accidents. Factors such as noise, insufficient illumination and thermal stress with high working speed and muscle fatigue produce high incidence rate of accidents.

The musculoskeletal problems also known as musculoskeletal disorder (MSD) is a common problem among waste collectors. The MSD can give effects to the waste collector's body such as muscles, joints, tendons, ligaments and nerves. For the waste collectors, the MSD were really relate to them in process of the handling of waste bag, bins, domestic containers and large containers. The work of waste collectors is characterized by an abundance of heavy work lifting as well as pulling and pushing of containers and carts. Thus, all these heavy work can cause the occupational risks factors for low back pain [9], [12]. In addition, the work of waste collectors may contain work above shoulder, frequent exertion of force, static contraction and joint positions which are occupational risk factors for MSD of the neck, shoulder and arms [9], [13].

Other than that, the waste collectors may have elevated incidence rates of work-related pulmonary, gastrointestinal and skin problems. The problems are caused mainly by exposure to bio-aerosols or volatile compounds. In addition, the bio-aerosol and volatile compound exposures of waste collectors may have a highly complex composition and the health problems may have multiple causes. Occupational allergic pulmonary disease such as asthma and allergic alveolitis may be caused by exposure to spores of molds from species of the genera Aspergillus and Penicillium which are particularly abundant in the work environment of waste recycling workers [9].

The gastrointestinal symptoms have been reported as a new and frequently occurring occupational health problem related to the collection of the biodegradable fraction of domestic waste [9]. The common gastrointestinal symptoms are diarrhea and nausea which are known as occupational health problems. Moreover, mucous membrane irritation problems were caused from the accidently spraying of percolate into the face and eye that resulting irritation and inflammation of the eyes and nose of the waste collector's workers [9]. Besides, almost the waste collectors work in high traffic density area that can lead them to exposure to the automobile exhaust, an example of these symptoms were most frequent in areas with high traffic density. The exposure to diesel exhaust also may cause irritation of upper respiratory tract [14]. 


\section{MethodolOGY}

This is descriptive and quantitative study. The study was approved by the Research Ethics Committee (Human) Universiti Sains Malaysia, Ref No: USMKK/PPP/JEPeM [248.4. (2.7)]. The participants involved in this study were waste collector workers from Mechanical Unit, Kota Bharu Municipal Council, Kelantan. This research conducted based on their routine job which are during their collect, transport and discharge the domestics waste into landfill. The total numbers of respondents were 103 [15]. The involvement of respondents (workers) is volunteer. However, respondents required to sign up consent form before the questionnaire form is given.

TABLE II: CRONBACH'S ALPHA TEST

\begin{tabular}{|} 
TABLE II: CRONBACH'S ALPHA TEST \\
\begin{tabular}{|c|c|c|}
\hline Sections & No. of items & Cronbach's Alpha Value \\
\hline Section 1 & 8 & 0.267 \\
Section 2 & 28 & 0.818 \\
Section 3 & 11 & 0.578 \\
\hline
\end{tabular}
\end{tabular}

TABLE III: FREQUENCY AND PERCENTAGE OF DEMOGRAPHIC DATA OF WASTE COLLECTOR WORKERS

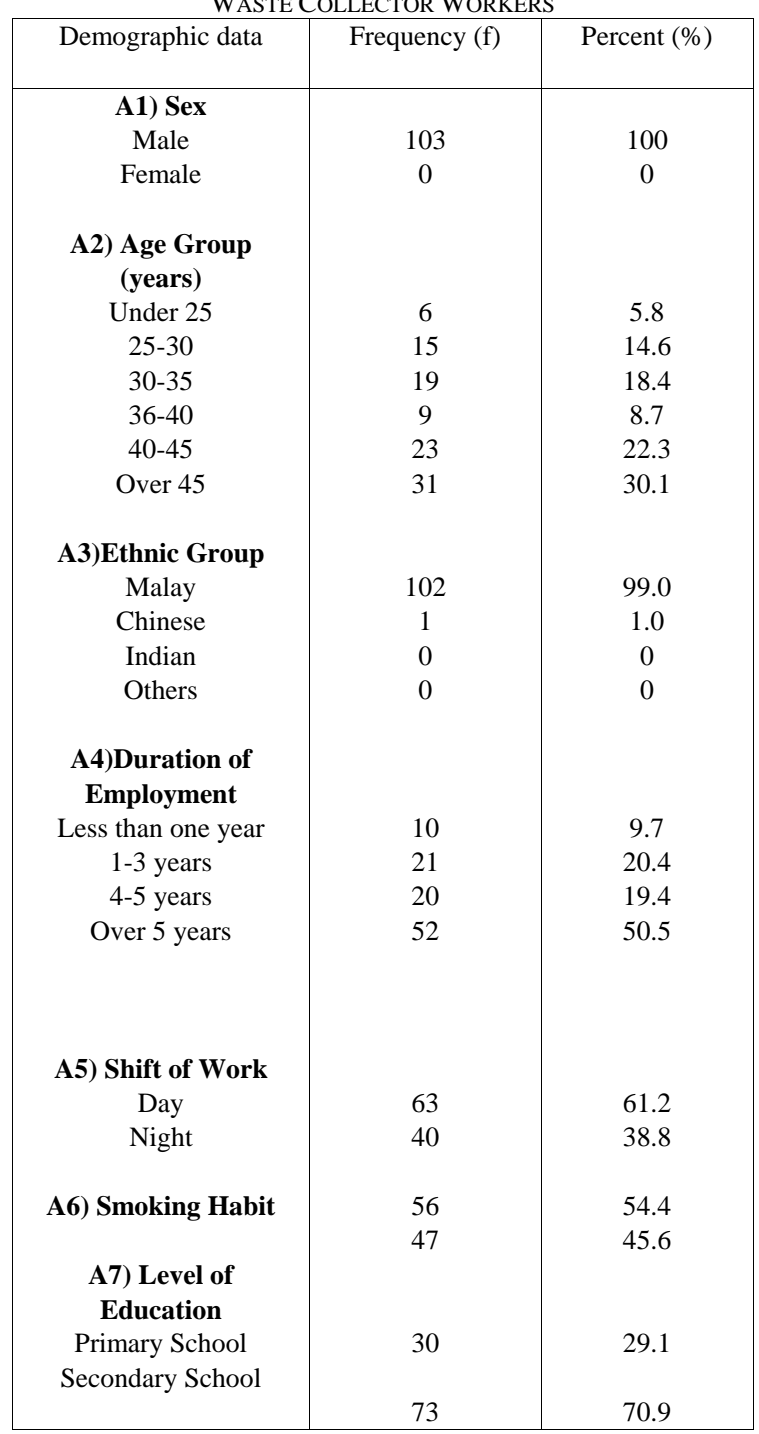

The primary data collection will be from questionnaire and direct assessment from the workers. The questionnaire was consist three parts. Section one is demographic information that are consist of eight questions that identified sex, age group, ethnic group, duration employment status, shift of work, smoking habit, level of education and frequency work in month. Section two were consist of six main questions that focus on health and safety policy, physical health risk, psychosocial health risk, biological health risk, ergonomic health risk and health symptoms. Section three ask respondent about their practices on the PPE. It also included the duty of employer about PPE enforcement and training for the workers. Besides, it also asked the subject about type of PPE such as safety vest, coveralls, googles, mask, gloves, hard hats and safety boots.

Cronbach's Alpha test was done to test the reliability of the questionnaire. The value of the cronbach's alpha for Section II and Section III are very reliable $(\alpha>0.5)$ (Table II).

The questionnaire data was analyzed using Statistical Package for Social Sciences (SPSS) in term of frequency, mean and percentage. In addition, the observation included the process of collection, transportation and disposal of the waste into the landfill area in Beris Lalang, Bachok, Kelantan.

\section{RESUlt AND Discussion}

\section{A. Demographic Data}

Demographic data analysis for the waste collector workers was shown in Table III. All workers are male. Most of the respondents $(30.1 \%)$ are over 45 years old. For the level of education, more than half of respondents which are 73 of them $(70.9 \%)$ were pass secondary school education. Regarding duration of employment for the waste collector workers, almost half or 52 respondents $(50.5 \%)$ were having employed over 5 years with MPKB. Based on data, 56 respondents $(54.4 \%)$ are smoker.

\section{B. Health Risk Information}

Health risk and health symptoms are proven to have an effect to the waste collectors. The result of these symptoms and problems were shown in Table IV. They was divided into five parts which are physical health risk (A1-A4) psychological health risk (B1-B3), biological health risk (C1-C3), ergonomic health risk (D1-D4) and health symptom (E1-E4).

Psychological health risk is refer to the problems that related to thinking, cognitive, stress and work process in the work place and give the back effects to the workers, employer and to the productivity of the work. There are three questions for this part. Biological health risk refer to poisonous animals, insect-carrying diseases, bacterial, fungal and mold in the workplace. The insect-carrying disease such as mosquitoes, cockroaches and flies are commonly found in the waste collection place and cause the biological health risk for the workers.

Besides, ergonomic health risk can bring a problems to body posture, repetitive movement, excessive stretching of the muscle and bending, sprain and swollen of the body posture. Normally, in the waste collection activities, there are various kinds of the health symptoms that affected the worker health status. There are consisting of respiratory health symptom, gastrointestinal health symptom, dermatological 
health symptoms and musculoskeletal health symptom.

In short, adverse health risk or health symptoms among waste collector in MPKB are physical health risk, biological health risk, musculoskeletal health risk and common health symptom such as cough, wheezing and phlegm.

Regarding musculoskeletal disorder, annual report from Social Security Organization (SOCSO) Malaysia mentioned that musculoskeletal disorder is one of the common health risks for waste collector workers. For example, in 2009, 161 cases were reported and it may include the accident or case from the waste collection industry workers. Waste collector workers of MPKB pretend to face heavy lifting, back pain and elbow or wrist pain cause by their work. The pain may cause from heavy physical activities, heavy lifting, repetitive movement, heavy uploading and downloading of waste and controlling the heavy mechanical of compactor trucks.

TABLE IV: FREQUENCY AND PERCENTAGE OF HEALTH RISK AND HEALTH SYMPTOM FOR WASTE COLLECTOR WORKERS

\begin{tabular}{|c|c|c|}
\hline $\begin{array}{l}\text { Health Risk and } \\
\text { Health Symptom }\end{array}$ & Frequency (f) & Percent (\%) \\
\hline $\begin{array}{l}\text { A1) Have you faced any sharp object } \\
\text { during work? }\end{array}$ & & \\
\hline Yes & 94 & 91.3 \\
\hline No & 9 & 8.7 \\
\hline $\begin{array}{l}\text { A2) Whole body vibration } \\
\text { is one of your problems } \\
\text { while working? }\end{array}$ & & \\
\hline Yes & 75 & 72.8 \\
\hline No & 28 & 27.2 \\
\hline $\begin{array}{l}\text { A3) Waste collection } \\
\text { activity required heavy } \\
\text { lifting job? }\end{array}$ & & \\
\hline Yes & 90 & 87.4 \\
\hline No & 13 & 12.6 \\
\hline $\begin{array}{l}\text { A4) Have you faced the } \\
\text { effect of heat from the } \\
\text { surrounding environment } \\
\text { while working (day shift)? }\end{array}$ & & \\
\hline Yes & 63 & 61.2 \\
\hline No & 40 & 38.8 \\
\hline $\begin{array}{l}\text { B1) Do you face any mismatch of } \\
\text { work environment to cognitive } \\
\text { skills, capabilities and limitation } \\
\text { workplace? }\end{array}$ & & \\
\hline Yes & 69 & 67.0 \\
\hline No & 34 & 33.0 \\
\hline $\begin{array}{l}\text { B2) Job stress is caused by } \\
\text { organization, environment or, poor } \\
\text { communication? } \\
\text { Yes } \\
\text { No }\end{array}$ & $\begin{array}{l}63 \\
40\end{array}$ & $\begin{array}{l}61.2 \\
38.8\end{array}$ \\
\hline $\begin{array}{l}\text { B3) Do you have a long } \\
\text { and irregular working } \\
\text { hours, working cycles, } \\
\text { or work shift? } \\
\text { Yes } \\
\text { No }\end{array}$ & $\begin{array}{l}46 \\
57\end{array}$ & $\begin{array}{l}44.7 \\
55.3\end{array}$ \\
\hline $\begin{array}{l}\text { C1) Have you come across } \\
\text { any poisonous/dangerous } \\
\text { animals while working? } \\
\text { Yes } \\
\text { No }\end{array}$ & $\begin{array}{l}91 \\
12\end{array}$ & $\begin{array}{l}88.3 \\
11.7\end{array}$ \\
\hline $\begin{array}{l}\text { C2) Any insect-carrying } \\
\text { disease (mosquitoes)? }\end{array}$ & & \\
\hline
\end{tabular}

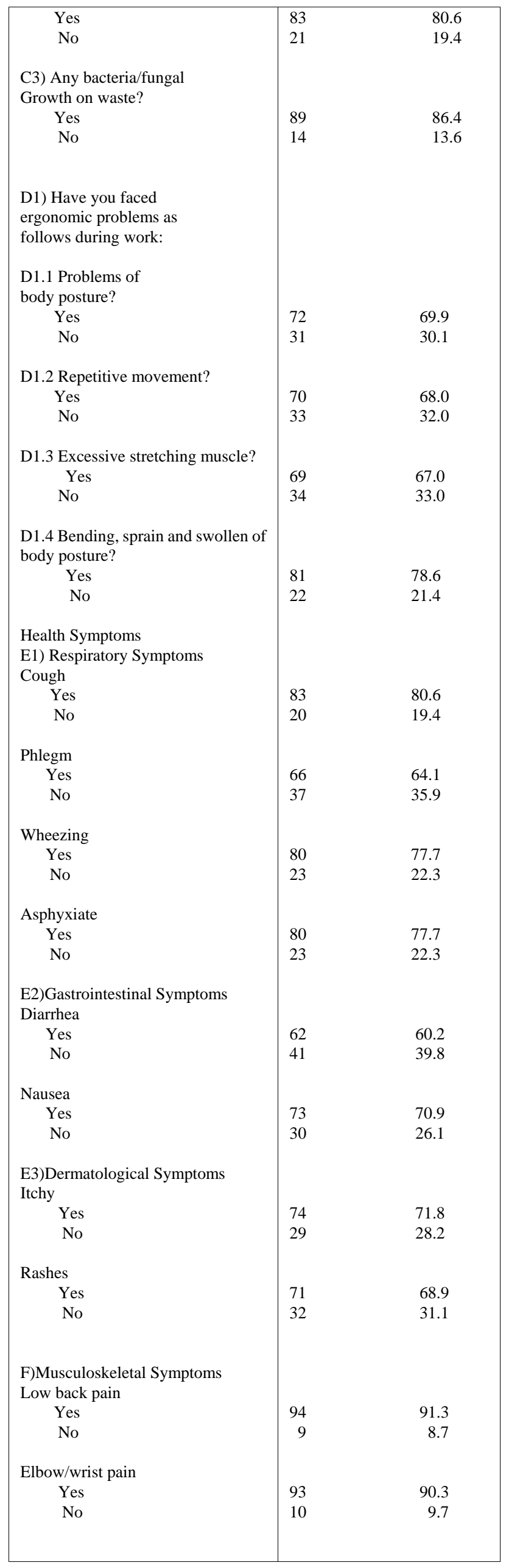




\section{Workers Practice on Personal Protective Equipment (PPE)}

The production, segregation, transportation and disposal of solid waste are involved the handling of potentially hazardous materials. Therefore, protection against personal injury is essential for all workers who are at risk. The common items of PPE for waste collector are helmets (with or without visors), respiratory face masks, eye protectors, coverall (long sleeve and pants), safety boots, glove and safety vest.

The highest mean value is belonging to the question number 1 (Q1: my employer supplies PPE) which is 4.37 out of 5.00. It showed that workers have notice that their employer has supply PPE for their work. Besides, mean value for question seven (Q7: I used the hearing protection if needed (noise level above 80 decibels)) and eight (Q8: I used the communication device - radio or cell phone in the case emergency) are the lowest as results 2.53 and 2.49. This showed that the workers at MPKB not really used their PPE such as ear protection and communication device while working.

For question number 2 (Q2: My employer provides training regarding the use of PPE) the mean value was 3.96. Regarding the use of PPE among workers during their works, the mean scored are 4.08 for question three (Q3: I used the long sleeves, pants or coverall), 3.54 for question four (Q4: I used the heavy leather work glove), 3.54 for question 5 (Q5: I used the safety boots during works), 3.34 for question 6 (Q6: I used the eye protection and splash shields as needed), 2.93 for question 9 (I used the hard hats in traffic areas), 3.48 for question ten (Q10: I used the safety vest in traffic areas) and 3.83 for question 10 (I used any types of mask at a needed condition).

In short, practice on PPE is one of requirement for the workers while do their works every day. Furthermore, employers must make sure that they protect their workers from any possible injury whilst at work. Besides, training session should be given to workers so that they are able to assess whether PPE needs to be worn, and it must always be available to them.

For the MPKB, regarding PPE issues, they already gave their workers a complete PPE when they sign as general workers of MPKB. Moreover, they also gave a training regarding to practice on PPE to their workers as comply with Malaysia Government Act, which is Occupational Safety and Health Act (OSHA) 1994. Section 15 (General Duties of employers and Self-Employed Persons) OSHA 1994 mentioned that the employee must make sure that safety, health and welfare at work of all employees. However, the workers in order to protect their self from any injury during their routine work must aware and have responsibility to use a PPE.

\section{Health Risk Survey}

There are fifteen common health risks that identified during the waste collection process. This study was done by followed the workers to their workplace and work area. The examples of health risks are in the compactor truck were sharp objects, heavy lifting, hazardous animals and chemical odor. The risk survey was summarized in Table V. The survey was divided into four section, work activity/situation, hazard, health effects and recommended control measures.

The locations that involved while the survey was conducted are as followed:

1) Taman Koperasi, Mukim Panchor, Panji

2) Taman Guru, Mukim Panchor, Panji

3) Taman Famili, Mukim Panchor, Panji

4) Dusun Raja, Wisma Nadia, Panji

5) Mukim Chakok, Panji

6) Taman Ishak Loffi

7) Maahad Muhammadi (L) An-Namuzaji, Pengkalan Chepa

8) Taman Hijau, Pengkalan Chepa

9) Lorong Masjid, Padang Bongor

10) Mukim Bongor, Pengkalan Chepa

11) Tapak pelupusan Sampah, Beris Lalang, Bachok

TABLE V: SUMMARIZE OF HEALTH RISK AMONG COLLECTOR WORKERS

\begin{tabular}{|c|c|c|c|}
\hline $\begin{array}{l}\text { Work } \\
\text { Activity } \\
\text { /Situation } \\
\end{array}$ & Hazard & Health Effects & $\begin{array}{l}\text { Recommended } \\
\text { Control } \\
\text { Measures } \\
\end{array}$ \\
\hline $\begin{array}{l}\text { Heavy } \\
\text { vehicles }\end{array}$ & $\begin{array}{l}\text { Physical/ } \\
\text { ergonomic }\end{array}$ & $\begin{array}{l}\text { Whole body } \\
\text { Vibration/ } \\
\text { noise/fatigue }\end{array}$ & $\begin{array}{l}\text { Enough rest/ } \\
\text { Take a rest }\end{array}$ \\
\hline $\begin{array}{l}\text { Congested } \\
\text { area } \\
\text { (inside the } \\
\text { vehicles) }\end{array}$ & $\begin{array}{l}\text { Physical/ } \\
\text { biological }\end{array}$ & $\begin{array}{l}\text { uncomfortable } \\
\text { area/bad odor }\end{array}$ & $\begin{array}{l}\text { House } \\
\text { keeping }\end{array}$ \\
\hline $\begin{array}{l}\text { Sharp } \\
\text { objects }\end{array}$ & Physical & $\begin{array}{l}\text { Hand and leg } \\
\text { injury }\end{array}$ & $\begin{array}{l}\text { Use suitable } \\
\text { glove }\end{array}$ \\
\hline $\begin{array}{l}\text { Heavy } \\
\text { lifting }\end{array}$ & $\begin{array}{l}\text { Physical/ } \\
\text { ergonomic }\end{array}$ & $\begin{array}{l}\text { Hand and leg } \\
\text { injury/ muscle } \\
\text { pain/cramps }\end{array}$ & Team work \\
\hline Heavy rain & Physical & Cold stress & $\begin{array}{l}\text { Use a rain } \\
\text { Coat }\end{array}$ \\
\hline $\begin{array}{l}\text { Muscle } \\
\text { contraction } \\
\text { (driver) }\end{array}$ & Physical & $\begin{array}{l}\text { Overuse muscle/ } \\
\text { Exhaustion/ } \\
\text { Cramps/ fatigue }\end{array}$ & $\begin{array}{l}\text { Take a rest/ } \\
\text { Enough rest }\end{array}$ \\
\hline $\begin{array}{l}\text { Small road } \\
\text { (traffic } \\
\text { problem) }\end{array}$ & $\begin{array}{l}\text { Physical/ } \\
\text { Psycho } \\
\text { social }\end{array}$ & $\begin{array}{l}\text { Accident/stress/ } \\
\text { Safety issues }\end{array}$ & $\begin{array}{l}\text { Use of road } \\
\text { Cone/safety } \\
\text { Vest }\end{array}$ \\
\hline $\begin{array}{l}\text { Long way } \\
\text { Drive }\end{array}$ & $\begin{array}{l}\text { Physical/ } \\
\text { Biological/ Psycho } \\
\text { Social } \\
\text { Physical/ } \\
\text { Psycho } \\
\text { Social/ } \\
\text { Ergonomic }\end{array}$ & $\begin{array}{l}\text { Sleepiness/ } \\
\text { Discomfort/ } \\
\text { respiratory } \\
\text { problem } \\
\text { exhaustion/ } \\
\text { fatigue/ } \\
\text { harm-leg cramps }\end{array}$ & $\begin{array}{l}\text { Use a } \\
\text { Suitable } \\
\text { Mask/face } \\
\text { Mask } \\
\text { Take a } \\
\text { Rest/ } \\
\text { Enough } \\
\text { Rest }\end{array}$ \\
\hline $\begin{array}{l}\text { Stress } \\
\text { Manage- } \\
\text { ment }\end{array}$ & $\begin{array}{l}\text { Psycho } \\
\text { Social/ } \\
\text { Physical }\end{array}$ & $\begin{array}{l}\text { stress/ attitude } \\
\text { management }\end{array}$ & Counselling \\
\hline $\begin{array}{l}\text { Repetitive } \\
\text { Movement }\end{array}$ & Ergonomic/physical & $\begin{array}{l}\text { Impaired or } \\
\text { Unsafe condition } \\
\text { and } \\
\text { Performance/ } \\
\text { Musculoskeletal } \\
\text { Disorder } \\
\text { Respiratory } \\
\text { problem/ } \\
\text { irritation on } \\
\text { skin and eyes }\end{array}$ & $\begin{array}{l}\text { Use a } \\
\text { Suitable } \\
\text { PPE/ } \\
\text { Enough } \\
\text { Rest } \\
\\
\text { Use a } \\
\text { suitable } \\
\text { mask/ } \\
\text { facemask }\end{array}$ \\
\hline
\end{tabular}




\begin{tabular}{|l|l|l|l|}
\hline $\begin{array}{l}\text { Hazardous } \\
\text { Animal }\end{array}$ & $\begin{array}{l}\text { Biological/ } \\
\text { Physical }\end{array}$ & $\begin{array}{l}\text { Severe wounds/ } \\
\text { Poisoning }\end{array}$ & $\begin{array}{l}\text { use } \\
\text { suitable } \\
\text { PPE/ } \\
\text { beware }\end{array}$ \\
$\begin{array}{l}\text { Insects- } \\
\text { Carrying } \\
\text { Disease }\end{array}$ & $\begin{array}{l}\text { Biological/ } \\
\text { Physical }\end{array}$ & $\begin{array}{l}\text { Dengue/ work } \\
\text { Related diseases }\end{array}$ & $\begin{array}{l}\text { use } \\
\text { suitable } \\
\text { PPE/ } \\
\text { beware }\end{array}$ \\
Watery & Physical & Slippery & $\begin{array}{l}\text { use a } \\
\text { safety } \\
\text { boot }\end{array}$ \\
\hline
\end{tabular}

In short, this study was important in order to know that they are many potential health risks while the workers handle the waste as their routine work. From the study, the waste collector workers will face more amounts of exposure and risks during their work compare with others workers. To prove it, in 2009 alone, about $18 \%$ from the total of incident cases was reported to Social Security Organization (SOCSO) was yield from waste management industry. Therefore, a comprehensive risk assessment of all activities related on the waste collection or waste management will allow the identification of necessary protection measures. Thus, workers knowledge about the work, health risk and practice on PPE is very important to prevent them from any incident or injury during routine work.

\section{CONClusion}

The solid waste management related to the human health risk. There are many of chemicals and biological agents used that contribute to the affecting the human health regarding on manage it. The waste collector workers will face more amounts of exposure and risk on their health during their work compare with other workers. In addition, their hard work requires repeated heavy physical activity such as lifting, carrying, pulling and pushing. Therefore, occupational accidents are very frequent among waste collectors. The musculoskeletal problems are also a common health risk to them. Generally, the most common reported accidents in the waste collectors were fractures, sprains, wounds, thermal accidents, soft tissue accidents, chemical burns and poisoning. Thus, practice and use on PPE is one of requirement for them in order to protect themselves from any possible injury and others health effects.

\section{REFERENCES}

[1] S. Bunrith, K. Hidehiro, H. Kimiaki, and K. H. Keiko, "Municipal solid waste management in Phnom Penh, Cambodia," Waste Management and Research, vol. 29, no. 5, pp. 491-500, 2010.
[2] P. Agamuthu and S. H. Fauziah, "Challenges and issues in moving towards sustainable landfilling in a transitory country - Malaysia," Waste Management and Research, vol. 29, pp. 13-19.

[3] Miller and G. Tayler, Environmental Science: Working with Earth, $11^{\text {th }}$ ed. United State of America: Cengage Learning, 2008.

[4] Environmental Protection Authority, Waste Guidelines, Adelaide: Service South Australia Government Legislation Outlet, 2009

[5] J. L. Domigo and N. Marti, "Domestic waste composting facilities: A review of human health risks," Environmental International, vol. 35, pp. 382-389, 2009

[6] R. Lesley, "Health hazard and waste management," British Medical Bulletin, vol. 68, pp. 183-197, 2003.

[7] M. P. Otto, O. B. Niels, E. A. Neils et al., "Collection of domestic waste: Review of occupational health problems and their possible cause," Occupational Health Journal, vol. 45, pp. 322-335, 1994.

[8] Waste management industry health and safety profile, Health and safety executive, Health and safety statistic in waste management and recycling (2009-2011). [Online]. Available: http://www.hse.gov.uk/waste/statistic.htm

[9] C. H. Yang, W.-T. Chang, H.-Y. Chuang, S.-S. Tsai, Wu T.-N., and F.-C. Sung, "Adverse health effects among household waste collectors in Taiwan," Environment Research Section A, vol. 85, pp. 195-199, 2000.

[10] T. Jorgen, B. Lena, and R. Ragnar, "Airways inflammation and glucan expose among household waste collectors," American Journal of Industrial Medicine, vol. 33, no. 5, pp. 463-470, 1998.

[11] I. M. Wounters, S. K. M Hilhorst, P. Kleppe, G. Douwes, C. Peretz, and D. Heederik, "Upper inflammation and respiratory symptoms in domestic waste collectors," Occupational Environmental Med., vol 59 , pp. 106-112, 2002.

[12] K. Jorgensen and F. Biering-Sorenson, "Standarized Nordic questionnaire for the analysis of musculoskeletal symptoms," European Spine Journal, vol. 18, no. 3, pp. 233-240, 1987.

[13] M. Hagberg and D. H. Wegman, "Shoulder musculoskeletal disorder: Evidence for work-relatedness," Journal of Occupational Disease, vol. 4, no. 2, pp. 214-231, 1987.

[14] P. T. J. Scheepers, V. Micka, V. Muzyka, R. Anzion, D. Dahmann, J. Poole, and R. P. Bos, "Exposure to dust and particle-associated 1-Nitropyrene of drivers of diesel-powered equipment in underground mining," The Annals Occupational Hygiene, vol. 47, pp. 379-388, 1992.

[15] V. K. Roberts and W. M. Daryle, "Determining sample size for research activities," Educational and Psychological Measurement, vol. 30, pp. 607-610, 1970 .

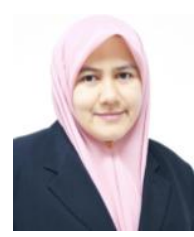

Haliza Abdul Rahman is an associate professor at the Environmental and Occupational Health Department, Faculty of Medical and Health Sciences, Universiti Putra Malaysia, Malaysia. Her research specialized in environment and development, environmental management, public awareness in environmental issues and current environmental issues. Currently, she is doing a research on participation and involvement of public in environmental issues, environmental management and social aspects of climate change issues.

She graduated from University of Malaya, Malaysia in 1998. Then she pursued her study in National University of Malaysia in 1999 for master degree in environmental management. In 2005, she got her PhD degree in environment and development also from National University of Malaysia.

Dr. Haliza published more than 35 journals, 75 papers in proceedings, 50 chapters in book and 12 books. She joined as an academia in university since 2005. From 2005 to 2013, she was a lecturer in Environmental and Occupational Health Programme, School of Health Sciences, Universiti Sains Malaysia before moved to Universiti Putra Malaysia in 2013. 